\title{
Weeping Qingdao Tears Abroad: Locating Chinese Publics in Colonial Malaya, circa 1919
}

\author{
R ACHEL LEOW* \\ Email: r1341@cam.ac.uk
}

This article suggests that conditions of coloniality produce a sui generis public sphere, one which contains multiple, plurilingual collective audiences, rather than a single "bourgeois public sphere" (Habermas), or a single "imagined community" (Anderson). By way of illustration, it locates diasporic Chinese publics in the colonial public sphere of British Malaya, and argues for a more analytically differentiated understanding of their constituent collectivities, or what it refers to as "we" publics. It analyses a Chinese-language newspaper, the Yik Khuan Poh, elaborating the different "we" publics convened within its pages, and emphasising the regional and translocal geographies of collective belonging that exist within the "transnational we," which models of diaspora tend to overdetermine. In situating the Yik Khuan Poh in its temporal and spatial contexts in the early twentieth century, this article also raises questions about the character of colonial public spheres in an era of significant globality.

Keywords: Chinese newspapers, May Fourth movement, anarchism, translocal, transregional

On 2 June 1919 a Huizhou native called Luo Jiongxiong issued a passionate call in the pages of a Chinese newspaper, the Yik Khuan Poh, founded just over two months earlier in the small colonial town of Kuala Lumpur in British Malaya. "Gentlemen of conscience, assist us," he implored, "we have been caused to weep Qingdao tears, and the national salvation spirit is raised within us!" Luo was a teacher at a local Chinese school, and a journalist, recently emigrated from China. These impassioned "Qingdao tears" were part of an upswell of Chinese nationalist sentiment around the postwar fate of Qingdao, the former German colony in the northeastern Chinese province of 
Shandong. ${ }^{2}$ Qingdao had been seized by Japan at the start of World War I-illegally, the Chinese representatives insisted - but after months of negotiation at the peace settlement at Versailles, on 30 April the Allies resolved in favour of Japan and confirmed the legitimacy of its claim on Shandong, much to the chagrin of Chinese onlookers. The result would be months of protest, not only by the students in Beijing whose violent protests on 4 May 1919 would gift the eponymous "May Fourth movement" to Chinese history, but by incensed Chinese compatriots across the country and indeed across the world. Luo was imploring these "gentlemen of conscience" to help him compile "Qingdao tears"poems, essays, lamentations, and other creative writings - into an edited volume which might be sold to raise funds for the anti-Japanese boycott that was at that very moment surging across Chinese cities on the mainland.

Who exactly had Luo Jiongxiong been addressing in his impassioned plea in the pages of the $Y K P$ - or to put it differently, who was included in the "we" that had been caused to weep Qingdao tears, and was now being called to arms? The classic theories of print and public spheres, by Jürgen Habermas and Benedict Anderson, tend to produce "the Chinese nation" as the answer. ${ }^{3}$ This is only too easily reinforced by the weight of Chinese diaspora studies, which on the whole remains devoted to elaborating the impact of mainland historical developments on overseas populations, such that the diasporic Chinese "we" and the mainland Chinese "we" are often subsumed one into the other. ${ }^{4}$

Yet this instinctively ethnonationalist answer is not particularly satisfactory. The picture of Chinese diasporic print culture which emerges from this is oriented towards nationalist struggle in China, in literary tone, in political galvanisation, in racialised national sentiment. But the nation Luo Jiongxiong wished to save was not, and specifically excluded, the territory in which he stood writing. His was a classically "diasporic" world, one which took as its object of imagination, concern, and sentiment a nation - "China" - that was decidedly elsewhere. Yet, writing in a Chinese newspaper that circulated primarily in Kuala Lumpur and other urban areas on the Malay peninsula, he could not have been addressing his countrymen there in China, but rather his similarly displaced compatriots here, the "we" that lay within the indeterminate geographies of the YKP's circulation. This was a particular public, one which tacitly shared an understanding of itself as differentiated and elsewhere from China. As Michael Warner observes in "A Conversation" in this issue, reflecting upon his classic work on publics and counterpublics:

When you're talking to people you don't know and you have to recruit them into some kind of we . . . it is an attempt to recruit people into [a particular] understanding. . . . But [this understanding] doesn't yet have a newspaper or an established press or a strong sense of what the geography of this community is. It is just going out into the world. It is that kind of motion outward towards strangers that produces a lot of the rhetorical and political forms of a public. ${ }^{5}$

Still more problematic is that, like many colonial spaces, British Malaya was a site of overlapping diasporic publics, bristling with competing intellectual and cultural geographies whose publics thought, spoke, and read in a range of different vernaculars, of 
which Chinese was only one. ${ }^{6}$ Colonialism's contact zones were products of direct conquest, large-scale labour migration, and the creole restructuring of economies and intimate spaces. Owing to the demographic artifice of the colonial intervention, many of its resultant worlds featured quite improbable "cohabitations" of language: Yoruba and English, to take Karin Barber's example, or a colonially appropriated Swahili and the many alternative vernaculars it elbowed out along the way, or the many topolects of Indian and Chinese languages that found their way on the decks of Portuguese, British, Dutch, and Spanish ships into Southeast Asian port cities and beyond. ${ }^{7}$ These processes produced overlapping polyglot publics that defy Habermasian models. Even Anderson's Imagined Communities, for all its profound wisdom about the ways in which national communities are imagined through shared languages of print, proved surprisingly inadequate to the task of imagining polyglot national communities, owing to its ultimately romantic (if "assuredly polemical") attachment to the idea of a single vernacular as the basis for amor patrie: "What the eye is to the lover...language - whatever language history has made his or her mother-tongue - is to the patriot. Through that language, encountered at mother's knee and parted with only at the grave, pasts are restored, fellowships are imagined, and futures dreamed". 8

This article thus proceeds from the observation that neither Habermasian conceptions of the public sphere nor Andersonian print capitalism adequately capture the character of a "colonial public sphere." Instead I want to explore the ways in which the colonial world's "sites of interaction" might instead produce a sui generis public sphere, one which contains multiple, plurilingual collective audiences, rather than a single "bourgeois public sphere," or indeed, a single "imagined community." Colonial print worlds seem to be uniquely dense with what Lara Putnam and Karin Barber respectively referred to as "expansive collective identities" and "multiple layers and scales of address" that were "simultaneous [and] nested within each other," from the most intimate to the most global and universal. In Putnam's words, the periodical press opened new intellectual spaces to address hitherto nonexistent collectives, producing "the ability to say 'we the Negro race, this is what we need to do," 'but also at the same time "to invoke multiple different collectives. Over the course of any given newspaper issue, editors might invoke island-specific collectives, such as Jamaicaness, and the British West Indian nation, and the British Empire."10 Benedict Anderson, some two decades after Imagined Communities, wrote of the prolific Ilocano-speaking Filipino patriot and journalist, Isobelo de los Reyes, that his youthful Spanish writings were "marked by the uneasy pronominal slippages between $I$ and they, we and you", that he was "always thinking about two audiences, even when writing for one and a half" - metropolitan audiences, fellow ilustrados, inchoate patriots, his as-yet unspecified hermanos of a revolution in waiting. ${ }^{11}$ In doing so, Anderson evoked the vertiginous instabilities of late colonial public spheres, engorged with audience collectivities in potentia, none of which had yet been fully bounded by the "serial logics" of institutionalized identities that would be the lot of so many communities passing through the colonial juggernaut. ${ }^{12}$

In Chinese newspapers in colonial cities beyond China, often regarded as simply derivative of or "hostage to [China's] political, economic and social trends of the 
time,"13 a range of collectives were also available for invocation which are ill-served by eliding them as simply "Chinese" or diasporic in nature. Refashioning the collectivities that converse, or are imagined, through the medium of print might help us move us away from the assumption of print communities as being coterminous with the national; an assumption which Rudolf Wagner, among others, has critiqued. ${ }^{14}$ This article suggests that to fully appreciate the characteristics of colonial public spheres, we need to think in more relational terms about the publics and the multiple scales of "we's" that newspapers invoke and convene in this flexible act of address. While studies of overseas Chinese newspapers have offered important correctives to histories of China by showing how Chinese press communities abroad may have played a far more important role in the transnationalisation or even emergence of Chinese nationalism, they have also tended to obscure how the same press helped create other senses of community, belonging, and concern. ${ }^{15}$

The newspaper analysed in this article, the Yik Khuan Poh (or the Yiqun Ribao), may be translated in English as "Benefit the Masses Daily."16 It was a Chinese-language newspaper for a primarily Hokkien-speaking readership in Kuala Lumpur, the largest city in the federated state of Selangor in British colonial Malaya. Its first issue was published on 24 March 1919, just over a month before the May Fourth protests broke out in Beijing, and it would be published continuously until 1936 - quite an achievement for a print newspaper at the time, by any measure. ${ }^{17}$ It was financed by local Chinese businessmen and Kuomintang sympathisers, as well as by capital canvassed and raised from regional elites and organisations: nearly half of its initial capital of fifty thousand dollars was acquired through the sale of shares to Chinese capitalists in the Dutch East Indies. ${ }^{18}$ By its own account, in its early years it had a circulation of around $1,700{ }^{19}$

In the first section, I examine the collectivities that are invoked and convened in the pages of the Yik Khuan Poh under the brief but vigorous editorial reign of the paper's first chief editor, Wu Dunmin, distinguishing heuristically between transnational and translocal "we" publics that coexisted within a single newspaper. In the second section, I appraise the editorship of a second the embeddedness of his journalism in a social network that spanned across the South Seas and to southern China, and examine the transregionality of his contributions to the $Y K P$. The distinctions I elaborate below between the transnational, translocal, and transregional are, naturally, more heuristic than mutually exclusive; I simply seek to use them to attempt to name the multiplicity of "we" publics that are convened within a single paper shaped by its colonial contexts. Finally in the third section, I turn briefly to consider the place of the $Y K P$ in the broader colonial print world of British Malaya, as one newspaper among many, and in doing so highlight a second feature of the colonial public sphere, as one further marked by the coexistence of multiple "we" publics, each ring-fenced by language while partaking in the synchronous globality of the early twentieth-century moment.

\section{Wu Dunmin: The Transnational and Translocal "We"}

Wu Dunmin was the founding editor of the Yik Khuan Poh, and he would also be its first political casualty, for he was deported by the British in the fall of 1919 for the 
unrepentantly radical editorials he published in the paper in the aftermath of the May Fourth movement. He was deposited on a ship to Hong Kong on 15 November 1919, ejected along with five other "undesirables" in what was referred to at the time as the "six gentlemen incident." ${ }^{20}$ It was an abrupt and unfortunate end to what had seemed like a promising career. When the Yik Khuan Poh was founded, Wu had been young, no more than thirty, and had been in Kuala Lumpur for less than two years. Born in Yongchun in Fujian province, to what must have been a relatively well-to-do family, he received a solid classical education and also spent some time studying in Japan, which is the most likely source for his anarchist convictions. ${ }^{21}$ It had been largely through his efforts and enthusiasms that the paper was founded. Wu's intellectual commitment, vigour, and eloquence captured the attention of local intellectuals in Kuala Lumpur, to whom $\mathrm{Wu}$ had been introduced by a fellow anarcho-communist, Wang Yuting, in the winter of $1917 .^{22}$

Wu's earliest editorials in the $Y K P$ on the whole reflect his ideologically anarchist concerns rather than nationalist ones, and are especially concerned with the sources of economic and social inequality. His first major essay in the paper, entitled "On the class system, and how it corrupts society," traced the historical emergence of class society and the growing gap between the rich and poor; here he proposed anarchism as the solution to social injustice in its commitment to social revolution and engineering social mobility, principally through education. ${ }^{23}$ Subsequent essays continue these themes, outlining a clear engagement with theories of mutual aid communism along Kropotkinesque lines, and the example to world socialism set by the Russian Revolution. ${ }^{24}$

The events of 4 May 1919 abruptly stimulated Wu's specifically nationalist reorientation. The first trace of May Fourth in the Yik Khuan Poh is a brief telegram on 12 May, little more than a terse reporting of the fact of the protests in Beijing a week ago. ${ }^{25}$ Three days later, Wu sprang into action, publishing a couple of short commentaries fiercely praising the actions of the Beida students: "Unafraid of peril, risking great danger and indifferent to censure, the Beijing students witnessed with their own eyes the destruction of the country and could not bear it, and so they acted out. . . . I hope our country (woguo, i.e., China) will follow suit, roll up our sleeves and work together to punish these criminals." ${ }^{26}$ It was only somewhat later, on 23 May, that the $Y K P$ was able to publish a full account of what had transpired in Beijing, an essay almost two thousand characters in length, offering a detailed description of the march through the diplomatic quarter of Beijing, the specifics of the banners which were hoisted and leaflets which were distributed on that day and subsequently, and a vigorous description of the break-in to Cao Rulin's house. ${ }^{27}$

A week later, Wu drenched the $Y K P$ in impassioned ink: he published seven open letters in quick succession on "the Qingdao question," and implored his readers to action. Staff and students of overseas Chinese schools must give moral support to the student protesters in Beijing and Shanghai, he urged. ${ }^{28}$ Overseas Chinese must convene meetings to organise anti-Japanese boycotts, which would constitute the most effective means of Chinese national defence, to complement and make possible the subversion and defeat of the Peking warlord government. He continued: 
What I have advocated and stood for these past few years has undergone a transformation. I had previously written off nationalism, and poured my energies into propagating the sacredness of labourism. So why am I now going on and on about Qingdao to my compatriots? It is because of these Japanese, who intend to enslave our government and people. . . . In the days to come, our compatriots must inflame their patriotism. Just as in Canada, in the Philippines, in Semarang, in Malacca: we must hold conferences, make plans. All of Kuala Lumpur's schools and educational circles and students, our Kuomintang branches, our shopowners: we must all be stirred to send telegrams, hold meetings, and in this manner invigorate the people's morale (minqi).

On 19 June, May Fourth happened in Singapore. Wu's open letters had undoubtedly laid some foundation for this. In the weeks following news of the events in Beijing, newspapers including the $Y K P$ wept tears, spilt ink, shook fists, and implored for action, calling for an uncompromising rejection of all things Japanese. News of the triple stoppage (san $b a$ ) in Shanghai between 5 and 12 June poured in via telegram: in an unprecedented show of solidarity with nearly a thousand students in Beijing who had been arrested on 3 June, not only Shanghai students but also merchants and workers struck in unison. ${ }^{29}$ Immediately afterward, Wu Dunmin published a primer with instructions on how precisely to coordinate an effective boycott, criticising the ongoing anti-Japanese boycott in Singapore and Malaya as disorganised and inconsistent in comparison, ${ }^{30}$ though at this point he explicitly, or at least rhetorically, counselled abstention from violent action. ${ }^{31}$ Finally, on 19 June, Japanese shops in central parts of Singapore, including Malacca Street and Bugis Street, were looted and goods burned in the streets. In other parts of Singapore, the altercations went beyond burning. Shots were fired into the crowds, the order to violence having been issued by A. H. Dickinson, the assistant superintendent of police. The next day, martial law was announced at 1:00 p.m., and the government announced a citywide ban on printing, publishing, or distributing any material "calculated to disturb the peace." 32 Armed forces remained thick on the ground for the rest of the week, as Japanese shops across Singapore closed to stem the flood of looting; the imperial Japanese consul issued circulars begging Japanese subjects to stay indoors and refrain from provocative actions, and opened the Japanese commercial museum to refugees. The unrest did not die down until 24 June.

This is the familiar, transnational "we" of the diasporic imagination: a great global community bound in sentiment and acting in cultural unison at the direction and urging of the motherland; a people bound together in the tears they wept at a sense of mass shared injustice. ${ }^{33}$ To use Michael Warner's language, if "a public is constituted through mere attention," this moment created a transnational public by galvanising its attention to a globally momentous event: more than simply cognitive attention, this moment was further characterised by "active uptake." 34

Yet as Arif Dirlik has emphasised, while overseas Chinese newspapers certainly "generated loyalties to the mainland, especially at times of crisis," they also "helped create a localized sense of community in those contact zones located in other national spaces, creating new cultural identities, and distancing Chinese migrants from their origins." 35 Even at this moment, which convened a strong transnational "we," attitudes manifested within 
its public with particular, contextual specificity. I outline two examples in which due attention to the specificity of the local enables a richer and more locally entangled understanding of how the transnational "we" publics functioned on the ground. Translocal approaches try to keep analytical focus trained on place as "the setting of grounded movements," to perceive at the same time "what flows through places," and "what is in them," and to try to understand both "simultaneous situatedness across different locales," and "situatedness during mobility." "The transnational "we" suggests a simple cultural and intellectual intimacy between people otherwise separated by vast physical distances; the translocal "we" is attentive to and insists upon understanding how those distances produce and maintain difference, and, I want to suggest, is more apposite to the kinds of historically and geographically situated Chinese communities found in colonial spaces on the margins of the Chinese world.

The first example reveals the way in which, in order to account fully for the sequence of events that comprise the May Fourth movement in Singapore and Malaya, we need to understand how ideas travel within a diaspora and are remade and re-performed in new print contexts. After the violent protests in Singapore and Penang in mid-June, Wu Dunmin, invigorated by the show of solidarity, began to think through the boycott and its ideological implications. Throughout July, he unleashed a flurry of think pieces in the $Y K P$, developing, among other things, his articulation of the concept of qiangquanzhuyi ("repressive authoritarianism"), widely discussed in the mainland Chinese periodical press, and which he agreed lay at the heart of China and Chinese people's ills. ${ }^{37}$ In four open letters on the nation (henceforth the "Minzu letters"), he developed a series of arguments against statism and state power, and argued for a new conception of nationalism, one which would be predicated on radical autonomy. Such a concept, he insisted, was irreconcilable with the military government in Beijing and its heavy-handedness, with arbitrary Japanese injustice exhibited at Paris and subsequently in China. All of these were, in particular ways, instances of repressive authoritarianism, and had in common four major institutions of repression: politicians, senators, army, and police. ${ }^{38}$ But it was the implicit juxtaposition with arbitrary British actions taken in the interest of "public security" in their colonies which Wu was developing in his writings, and the way in which he was hitching a transnational anti-Japanese critique to a local, anti-colonial one, that began to evoke the suspicions and scrutiny of British colonial authorities. Over the ensuing month of June, Wu had already been twice summoned to the colony's principal institution for policing Chinese communities - the Chinese Protectorate-and reprimanded. ${ }^{39}$ His Minzu letters were the last straw. After the fourth letter appeared he was arrested, along with Song Mulin, Zhao Shichi, Yang Jianhong, Yang Yaoguang, and Li Ximeng, on 29 July 1919, and stood trial several weeks later. ${ }^{40}$

On the very first day of his trial, on 20 August 1919, Wu's stand-in editor at the YKP "cut" and republished a famous May Fourth article as an editorial: an essay by Beijing student writer Tan Mingqian entitled "Aspects of Democracy," originally published in Xinchao the day after the first protests in Beijing back in May. ${ }^{41}$ In this essay, Tan, responding powerfully to the immediate aftermath of the events of 4 May in Beijing, asserted his understanding of democracy as a loose umbrella concept driven by basic 
principles of equality and liberty, rather than something ideologically Marxist, and that adherence to democratic principles was a "way of life" that ensured, among other things, the "victory of reasonable truth over unreasonable force" (gongli zhansheng qiangquan). ${ }^{42}$

This act of re-publication might be dismissed as a merely obvious feature of the "transnational Chinese press" - newspaper content in an overseas Chinese paper was of course routinely filled and padded out with copy from mainland Chinese papers, in a common genre practice known as jianbao (literally, "cutting newspapers"). ${ }^{43}$ But analysing it in the modes of the colonial public sphere and the particular way in which it appeared in the $Y K P$, we might understand this as a performative act of re-publication, one designed to make a pointed jab at what the editors undoubtedly viewed as a thoroughly unreasonable colonial state. Tan Mingqian's piece itself had not been altered; there was no editorial comment introducing it, and no attempt to change it in any way to make it relevant to local circumstances. But the timing was unmistakable. Republishing Tan Mingqian's article on that particular day lent weight to Wu's trial for protesting against qiangquan. Addressed to a differentiated, translocal Chinese public and appearing in print in quite different contexts, its readers in this distant colonial public sphere would have read or heard it in a fundamentally different way than its original readers in Beijing. The act of re-publication here created a semantic field in which the qiangquan, the unreasonable authoritarianism, of Japan in the global sphere at distant Versailles, could be juxtaposed with that of Britain in the nearby space of Kuala Lumpur. Through this mode of directed addressivity, it convened a local, diasporic Chinese community of agitated readers who were very much "here," with Wu Dunmin, rather than "there" with Tan Mingqian.

The convening of a translocal public also became visible in action. Wu Dunmin's editorial tenure convened two such publics. The first gathered on the occasion of his arrest, when a mass general strike of over eight hundred Chinese shops took place in Kuala Lumpur in protest; a second strike was called on 12 August $1919 .^{44}$ This was a moment of strike action specific to the Chinese community in Kuala Lumpur; it happened nowhere else. Though the protesters were undoubtedly primed with the organisational tactics and the passions of transnational protest a mere two weeks ago, the proximate cause of their actions was the affront to a decidedly translocal "we": the Kuala Lumpur-based Chinese reading public, whom the YKP addressed, and called to action, on the matter of Wu's arrest. ${ }^{45}$ The second translocal public gathered on the occasion of his expulsion. Wu was sentenced for deportation on 24 October 1919. On the day the police cordon departed Kuala Lumpur for Singapore, over two thousand spectators - a convened public of agitated readers who were "here" with $\mathrm{Wu}$ - thronged the roads, continuing to protest. On 15 November, Wu and his comrades were deported from "here" to "there"- in this case, from Singapore to Hong Kong, and then onward to Yongchunand would never set foot "here," in Kuala Lumpur, again. ${ }^{46}$

\section{Liu Kefei: A Transregional "We"}

When it came to printing politics, as with many other Chinese newspapers, principal editors had a strong impact on the tone of the paper. The Yik Khuan Poh was no exception. 
We have seen how Wu Dunmin's brief tenure at the paper in the aftermath of May Fourth escalated its patriotic tone; he gathered around him a group of writers committed to the cause of inflaming Chinese nationalist passions in their readers, and his journalism was oriented to what I call the "transnational we": the pronoun of the global Chinese patriotic masses. A different contemporaneous editor, also deeply influenced by the May Fourth movement, corralled his interests in different ways. Liu Kefei's editorial tenure suggests the possibility of a "transregional we," one that was embedded in his transregional social, familial, and journalistic networks. ${ }^{47}$

Liu Kefei served as the editor of the Yik Khuan Poh from May 1920 to March 1921. He frequently signed his editorials as simply "Kefei." The omission of his family name is a symptom of his ideological commitments: like many other southern Chinese anarchists influenced by the great Chinese anarchist Shifu, Kefei renounced the surname-and indeed, the nation - as an impediment to the creation of a universal human family and brotherhood of men. And it is no surprise that he was influenced by Shifu, who was, after all, his elder brother.

Shifu died young, of tuberculosis and probably overwork, in $1915 .^{48}$ At the time, Kefei was too young to participate in the activities that sought to continue his brother's work, principally labour organisation and propaganda work in Guangzhou, Shanghai, Zhangzhou, and other southern centres of radical activity. Another older brother, Liu Shixin, had been much more active. Closer in age, he had been more deeply involved in Shifu's intellectual development; during Shifu's imprisonment in 1907-1909, Shixin had been just twelve years old, but had visited his brother in prison every week, bringing him classic texts and copies of the Chinese Paris-based anarchist periodical Xin Shiji (New Century) to read together. ${ }^{49}$ In November 1916, the year after Shifu died, Shixin travelled to Southeast Asia in the company of Liang Bingxian, an eloquent journalist, anarchist activist and disciple of Shifu, and a close friend of the Liu family. ${ }^{50}$ Bingxian was a seasoned traveller in the region: he had been at least twice before, once to Singapore and once to Rangoon, and in both places he left behind a few anarchosyndicalist pamphlets of his own composition. ${ }^{51}$

In 1916, after Shifu died, Shixin and Bingxian headed to Singapore and taught for a while in Yeung Ching (Yangzheng) School, a private Cantonese school established in 1905. Yeung Ching had strong connections to Guangzhou, and imbibed something of its revolutionary fervour, promoting a distinctly progressive agenda throughout the 1910s and highlighting, especially, the importance of educating women. After Bingxian returned to Guangzhou, Shixin stayed on in Nanyang, travelling to Sumatra with seven other writers to spread socialism and anarchism through newspaper work, though he conceded in his memoirs that their techniques of activism and propaganda were rather immature. ${ }^{52}$ Shixin edited a paper called the Sumatra Paper (Sumendala bao). This periodical quickly attracted the attention of the Dutch authorities - "they called me a Bolshevik," Shixin recalls — and he was deported in the fall of 1919.

These were the regional contexts and social networks within which, in the spring of 1920, Kefei was invited to Kuala Lumpur to edit the $Y K P^{53}$ At the time, he had just left a position as a journalist at the Manila-based paper the Common People's Daily (Pingmin 
ribao). ${ }^{54}$ His tenure at the Yik Khuan Poh lasted just under a year, from May 1920 to March 1921, after which he was, like his brother, deported and sent back to China. His impact on the paper, though, was immediate. In terms of form, Kefei greatly enlarged the physical size of the paper to accommodate more and longer articles. He also installed a new supplement, Freedom Talks (Ziyoutan). Freedom Talks was an explicit introduction of May Fourth and New Culture thinking into Kuala Lumpur. It was conceptualised as a space for learning and discussion, and contained the following sections: The Discussion of Questions, New Thought Trends, Research and Learning, and Reader Opinions. It also included a letters column, which printed an abbreviated version of a letter, usually styled in classical Chinese prose, followed by Kefei's considered response. ${ }^{55}$ The emphasis was on reader interaction rather than monodirectional editorials.

In terms of content, Kefei brought a focused revolutionary momentum to the $Y K P$. He also demonstrated a broad intellectual and ideological flexibility, willing to publish a wide range of contending points of view, and this openness would characterise much of the YKP until the watershed Shanghai massacre in $1927 .{ }^{56} \mathrm{In}$ all, according to the analysis by $\mathrm{Xu}$ Jianfen, Kefei wrote around one hundred fifty articles during his eleven months at the YKP. By this measure, he was certainly not as prolific an editorialist as Wu Dunmin, who penned some 264 items in less than six months. ${ }^{57}$ Yet Kefei's principal contributions were less about opinionated editorials and more about what we might think of as his bricoleurship: the ways in which he curated and gave space to a range of opinions that "allowed many different political and intellectual positions to flourish . . . exposing local Chinese to a whole new political atmosphere." 58 As with many papers of the day, what was offered in Freedom Talks was not just reportage, but pedagogy: social facts became implicitly didactic, serving as exemplars of progress and modernity. ${ }^{59}$ The scale of reform which seemed to matter most to Kefei personally was that of the cultivation and reform of individual habit (xiguan), one of nonspecific ethnicity or origin, which would translate and ripple outward to effect revolutionary change at all subsequent scales. Change the habit, Kefei believed, and one would change the world. In this, he was perhaps echoing the beliefs of the Guangdong anarchist warlord Chen Jiongming, with whom his brother Shixin was personally acquainted. ${ }^{60}$ As Chen had written in the Fujian Star in 1919: "If we resolve to work for the benefit of the world, we must start with the reform of China; to reform China, we must start with the reform of our minds. . . Once our minds are reformed, new opportunities will naturally follow." ${ }^{\circ 61}$ In the $Y K P$, Kefei sought to put this into practice among the natural "communities of interests" which Southeast Asian Chinese seemed to perfectly represent, and to nurture a revolution in habit from the ground up. ${ }^{62}$ His insistence on practice shaped by theory distinguished his editorial regime: as Xu Jianfen says, "Liu's anarchist commitments were evident not only in the tenor of his writings but also in the method of his execution through his activities at $Y K P$."63

On the one hand, Freedom Talks featured articles which Kefei selected and "cut" directly from prominent New Culture journals from Shanghai and Beijing. Many of these articles skewed intellectually against nationalism, capturing some of the cosmopolitan spirit that very much characterised currents in Chinese thinking at the time. The very 
first issue of the column, for example, serialised a lengthy article by socialist thinker Dai Jitao, which criticised nationalism as the basis for revolution, and insisted that the Russian Revolution was not a national revolution, but a particular iteration of world revolution. Freedom Talks also featured serialised translations of important European and Japanese writings - for example, Rousseau's "Discourse on the Origin and Basis of Inequality among Men," or an essay on Chinese culture by the famed Sinologist Inaba Iwakichi, which was syndicated from the Taiyang Zazhi and reprinted in the YKP with an introduction by Kefei. ${ }^{64}$

On the other hand, alongside these articles of transnational Chinese or worldcosmopolitan interests "cut" from Shanghai papers, Kefei also deliberately juxtaposed articles dealing with matters of concern to internally differentiated publics of Chinese-speakers in Kuala Lumpur, and solicited correspondence and discussions about them that showed their principles applied in practice. To take an example, Freedom Talks was one of the few spaces in early Chinese newspapers where local women correspondents were frequently featured. Kefei's views were radically progressive: "The question of the liberation of women," he declared, in one of his earliest essays, "is really just the same as the question of the liberation of women's education." 65 Throughout the months of November and December 1920, he cut and republished cosmopolitan articles - a lengthy translation of Alice Chapman Dewey's speech in Hubei, which insisted that the question of women's education ought to occupy the same central place in political discourse as that of the Shandong question, and speeches by Bertrand Russell, which emphasised the same. He also inserted news on the various statuses of women across the world. ${ }^{66}$ But in fulfilment of his belief in the need to reform individual minds, he juxtaposed these alongside letters in the Tongxin column featuring local women's reactions to these views, some of which he appears to have solicited specifically from his networks. For example, he featured several letters by a woman named $\mathrm{Wu}$ Huilan, from Klang, who having followed the discussions in the YKP for several weeks, announced to Kefei that she sought to marry a more intelligent man by requesting that they send essays to his Freedom Talks, in order that she might choose her husband by choosing the best of them; Kefei collected and published letters from other local women in support of her "progressive" action; ${ }^{67}$ he also solicited opinions and reactions to recent articles he selected from women readers, which he collated and featured periodically. ${ }^{68}$

Apart from the focus on individual practice as refracted by world trends, Kefei also attended to the regional, drawing on his own social networks to do so. As Bryna Goodman has observed, "the geographic imagination expressed through newspaper format . . . indicates the complexity of newspaper identity, suggesting a variety of extranational (and sub-national) imagined spaces left unexamined in Benedict Anderson's focus on the 'imagined community' of the nation." ${ }^{69}$ The YKP had always featured separate sections for "world news" (shijie yaowen), "news from Guangdong" (Guangdong xinwen), "news from Fujian" (Fujian xinwen), and eventually "news from Nanyang" (Nanyang xinwen). It cut and republished articles from major Chinese magazines and periodicals of the May Fourth era, as suggested above; but it also advocated that their modern, enlightened, and well-informed readers in Kuala Lumpur should feast on a 
regional progressive media diet. It recommended a fraternal network of newspapers that stretched across the South Seas: Sibin Ribao (Surabaya Daily); Xianluo Ribao (Siam Chinese Daily); Sumendala Ribao (Sumatra Daily); Juemin Ribao (Awaken the People Daily); Huazhong Bao (Chinese Bell Paper); Zhenli Zhoubao (Truth Weekly), based in Semarang; and Pingmin Zhoubao (Common People's Weekly), the Manila-based weekly where Kefei had worked before coming to the YKP. Many of these were edited by fellow anarchists with strong fraternal connections to each other and lodged in a transregional space that stretched from Medan to Manila and up to Guangdong. Headlines, major news items, and even reader letters were also periodically syndicated from these regional papers, alongside the modern offerings from the mainland. ${ }^{70}$

Lara Putnam has argued that anti-colonial internationalism emerged out of the transnational space made available by the periodical press for "the sharing and comparison and analysis of the experience of anti-black racism," and that it enabled people to draw explicit comparisons between distant places in the world- "between what's happening in the Rand or what's happening in Cape Town."71 The "bricolaged" quality of Freedom Talks and the YKP under Kefei created new horizons for comparison that specifically included the regional. Some of these sources naturally drew on Kefei's own contacts in the region. The publication of a lengthy serialised report of travel to the Philippines in Freedom Talks, for example, was certainly related to Kefei's own experience in Manila, as well as connections he had made there. ${ }^{72}$ Shuai Shugeng, the writer, had been recruited in 1915 by the Manila-based New Fujian Newspaper to serve as a writer and commentator. By 1920, like Kefei, he had found his way to the Malay peninsula, and was serving as a teacher at the San Yuk Public School in Rawang, a district to the north of Kuala Lumpur, as well as contributing to the YKP by Kefei's invitation. Shuai had a clear comparative sense of what it meant to be a subject of two systems of colonial rule and offered his factual reporting as a commentary on comparative features of the modern. His comments on the architectural impressiveness of Manila, the excellence of its healthcare system and public hygiene, the American government's provision of public entertainment, and the egalitarian qualities of its legislative council were direct comments on the much-lower standards of these indices of good living under the British in Malaya. There was hardly any crime, he said, because although there were not many police, there were many detectives. "The US is the world's biggest advocate of equality and humanity," he wrote, and this was what led them to ban inhumane things like rickshaws and cockfighting. More Filipinos wore socks and eyeglasses under the Americans than ever had under the Spanish, as a direct result of the new common education introduced from America and the improved medical system. "The living standard in the Philippines," he concluded, "is twice more than that in China and double that of the Malay Peninsula." $" 73$ The horizons of comparative modernities were thus not simply binary, between "East" and "West," but also encouraged envious sideglances across nearby communities living under different kinds of colonial rule outside China, further differentiating "we" communities within the $Y K P$.

Thus the many "we's" invoked in Freedom Talks that slid easily from one scale to another went from the individual through to the global, via the regional. In response 
to a reader's effusive praise about Kefei's interventions and innovations in Freedom Talks, Kefei wrote: "We Chinese, when reading the newspaper, finish by reading only local news, and remain unconcerned about what happens in other places. This is not a good habit, because 'we' are people of the world, and events which happen in the world require us to have a little understanding in order to grasp them." His interlocutor agreed with a different "we": "We Nanyang Chinese are frequently only able to spout the names of newspapers, but we do not understand, really, what newspapers are," Jianzhi replied. "We do not know that ultimately, newspapers shoulder the whole responsibility of the world's reforms. . . . We Nanyang Chinese thus forfeit the opportunity to be in tune with world culture."74

I have emphasised Kefei's ideological commitments as an anarchist because it seems to me that his anarchism disposed him to think universally even as he acted regionally and locally, and to be uniquely conscious of the multiple scales of political and social action. $^{75}$ To paraphrase Michael Warner, Kefei was merely "going out into the world" with his pen, hailing geographically indeterminate audiences that were both more and less than the scale of the nation. As Tony Ballantyne and Antoinette Burton have cautioned us, "we need to be aware of the limits of the nation-state as a way of organising our understanding of cultural change between 1870 and 1945."76 Perhaps even more so in the case of sojourning Chinese communities, who are so often studied in frameworks that take an ethnicised nation-state along with them, assuming that "overseas Chinese nationalism" is the only story which underwrites their historical subjectivity. Their regionality was certainly one of the scales of "we" publics that were convened in the YKP.

On this ideological basis, it might even be possible to see Liu Kefei and his brothers not as vessels of Chinese "diasporic" influence in the South Seas, but as nodes in a polyethnic network of global radicalism and ideological bricolage that spanned the late imperial world and the early twentieth century, which found local, regional, and global expression simultaneously in vernacular idioms of universal social justice, individual liberation, and cultural renovation, and were fashioned and transformed in a range of social and historical conditions. ${ }^{77}$ The intellectual genealogies of Chinese anarchism - as yet much understudied - have tended to be established in relation to the emergence of Chinese communism, a relationship that has been inherited obediently in analysis of its emergence among emigrant Chinese communities, where little attempt has been made to index its global, rather than diasporic, nature. ${ }^{78}$ What this more global "we" came up against, in the complex colonial public sphere of British Malaya, was language.

\section{The Coexisting "We's" of the Colonial Public Sphere}

The final "we" I examine speaks to the distinction frequently made in context of discussions about the Habermasian public sphere: that between the "private" and the "public." For Habermas, this distinction seemed to have derivations from Greek: the sphere of the oikos (hidden, private, individual interactions in the domestic or intimate realm) and the polis (open, public, collective interactions in the political or statist realm). This 
distinction makes little sense for the broader colonial space in which the $Y K P$ operated. Notwithstanding Rudolf Wagner's recent admonition not to "mind the gap" between languages within a given multilingual print space in order that we might better appreciate the globality of the cosmopolitan public sphere of Shanghai, ${ }^{79}$ the colonial public spheres of Malaya and Singapore at the heart of this study in this period seem, instead, to consist in the coexistence of multiple effectively private spheres of discourse, each isolated from the other by the boundaries of language. Within them, "publics" could exist without being overheard by others who occupied the same public, physical space, and their "gaps," so to speak, were very much minded by a watchful colonial state.

The case of the May Fourth movement in Singapore and Malaya throws this into special relief. Despite the lead-up of over six weeks in the Chinese-language press, the events of 19 June appeared in the English-language press as an eruption of irrational mob rule, an unprecedented menace to the "general public" and to the rust en orde of colonial rule. Much reference was made to "gangs of Chinese rowdies," "crowds of excitable Chinese coolies," "disturbance," "trouble," and "turmoil," and the restoration of peace and order after a week of violence which, at one point, was even referred to as a "holocaust." "Fo "Five Fatalities," one headline shrieked; its byline: "Effective Government Measures." No attempt was made to understand the nature of the grievances. Instead: "Public inconvenienced." The general strike on Friday 1 August in Kuala Lumpur, convened to protest Wu Dunmin's arrest, also appeared as though out of the blue. The peninsular-based Malay Mail was the first to pick up the story: "The first intimation that the general public had yesterday of anything out of the ordinary happening in Chinese circles was the closing of all Chinese shops in town." ${ }^{" 81}$ Three days afterward, the Singapore Straits Times finally published an article catching up on the events in Kuala Lumpur. ${ }^{82}$

That this was so is not surprising. Looking through the English-language colonial press, predominantly the Straits Times, the counterpart Times of Malaya, and the Singapore Free Press, it is very clear that the aspects of the event that mattered to those attention publics were coverage of the terms of the peace treaty as it pertained to Germany; they were interested mostly in ensuring minimal disruption to the healthy continuation of business and capital. ${ }^{83}$ There were only a few explicit moments of intersection with Chinese attention publics. One was a letter published on 13 May in the Straits Times by a Chinese reader from Malacca who signed off as "Most Exasperated," lamenting the decision on Qingdao as a "serious menace to [China's] sovereignty and integrity." ${ }^{\prime 84}$ Another was the translation in the Singapore Free Press of a somewhat threatening letter, dated 23 June, that had been sent to a Chinese employee of a Japanese firm: "The anger of the students and the boycott of the merchants are examples of our countrymen's patriotism. . . . If you do not carry out our advice [to sever your employment at the Japanese firm] within a week, blood will be seen." ${ }^{85}$ These moments of intersection between two essentially discrete publics were few and far between.

The YKP's location in Kuala Lumpur also mattered. Tucked away farther up the peninsula, it was largely insulated from the more policed spaces of Singapore, and much less subject to the kind of scrutiny that its Singaporean counterpart, the Guomin Ribao, 
received. On 28 May, the $Y K P$ reported that the government in Singapore had been inspecting and censoring Chinese newspapers, in particular intercepting and censoring articles about the Qingdao problem. Like the YKP, the Singaporean Guomin Ribao had been immediate and vigorous in its response to the events in Beijing, advocating an anti-Japanese boycott at around the same time as the $Y K P$. But where the YKP continued to put out its vigorous articles throughout the summer of 1919, at least until August, the Guomin Ribao was shut down by the British authorities in Singapore almost immediately, and was only able to resume publication in October that year, under a new name (Xin Guomin Ribao), and with a somewhat more subdued editorial tone. The reasons for this are likely to do with the relative paucity of police oversight of the Chinese communities in Kuala Lumpur, compared to Singapore. The Chinese Protectorate simply did not have enough translators on the ground in Kuala Lumpur to scrutinise and censor the Chinese-language press in a timely fashion. ${ }^{86}$ The Singapore Free Press editorial for 23 June observed as much:

There is some grounds for criticism that [the unrest] might have been foreseen by the Government. . . . At the same time, it must be recognised that if the Chinese choose to adopt a policy and organise a movement, the Protectorate is up against a stiff proposition if the Chinese decided to keep it secret. No man can be more secretive, and profess to know less about any matter in dispute, than a Chinaman. ${ }^{87}$

The latter statement, a rehash of the usual orientalist tropes about the inscrutability of the Chinese, is more usefully regarded as a reflection of the gulf (or, to use Wagner's term, the gap) between the English- and Chinese-language publics. As the above discussion of the YKP suggests, there was nothing very secret about the discussions which led to the boycott. Wu Dunmin's vigorous advocacy was "hidden" in plain sight: a "public sphere" walled off by language, which remained private until enacted in event, and which, perhaps because of this, immediately assumed the dimensions of crisis. It is not surprising that it was this series of incidents in the summer of 1919 that precipitated a new wave of tightened colonial control over the Chinese communities of Singapore and Malaya. In the following year alone, a suite of punitive regulations were hurried through the Straits Legislative Council and passed, almost without opposition. These included new ordinances on passenger restriction, the reinvigoration of an older seditious publications ordinance to place new restrictions on the flow of literature from China into the country, the amendment of a naturalisation ordinance to allow the colonial state to revoke alreadygranted naturalisation certificates, new regulations and registration requirements on printing presses, and most critically, the surveillance and registration of Chinese schools, which had been reckoned by the colonial government to have been at the root of most of the agitation.

This "walling off" of one public from the other has been noted in another cognate colonial context, that of Hong Kong. "We British in Hong Kong appear to have built a Great Wall between ourselves and the Chinese," Beilby Alston wrote to Francis Tyrell at the British legation in Hong Kong, in the aftermath of the Hong Kong seamen's strike in the early months of 1922 : 
We and they live in different worlds, mentally, politically and socially. For us, Hong Kong is a little bit of England; and for them, it is one of the gates of China. Our newspapers discuss the Irish Question, the Genoa Conference, or mosquitoes at the Peak, and all but ignore the existence of China; during five days of April [1922], momentous for China, the only news from parts of the country other than Canton which appeared in our English press was a telegram saying that there was a great congestion of passengers and mail at Shanghai owing to the railway line being interrupted between two stations which do not exist. The Chinese press of Hong Kong, on the other hand, writes of Chinese politics and affairs in the same manner as if its organs were published in China; almost as if the government of Hong Kong was just a temporary accident and as if its acts and decisions were too trivial to be mentioned in the same breath as those of a provincial satrap in China. ${ }^{88}$

If delving into a single newspaper reveals a range of "we's," from the intimate to the regional to the universal, it is a second contention of this paper that colonial public spheres are further marked by the coexistence of multiple "we" publics within the same colonial territory, ring-fenced by language, between which a reader might move only by virtue of translation or multilingualism. The overlapping and coexistence of these multiple publics might be regarded as a basic quality of a colonial public sphere, particularly in those as multilingual as found in the British colonies of Malaya and Singapore, the latter frequently referred to as a kind of Eastern "Babel," ${ }^{\prime \prime 9}$ and to a lesser extent owing to its comparative linguistic homogeneity, Hong Kong. Filled with improbably cohabitant print vernaculars jostling up against each other, colonial Malaya's "public sphere" might be understood as a product of many convergent elsewheres, each of which produced numerous indeterminate "we" communities bounded by language, and embedded in geographies and circuits of ideas that were at once cosmopolitan and particular, at once transnational, transregional, and translocal. Malay-language papers looked westward through the Indian Ocean to a newly reformist Middle East, infused with Arabic, Sanskrit, Tamil, and Persian vocabularies and literary genres; Chinese-language papers looking north and eastward, grappling with currents of language reform and modern ideologies coursing through a Sinophone world, and shading at its experimental edges into hybrid and creole varieties; English-language papers that looked uneasily to a colonial metropole, modifying or refusing its cultural imprimaturs. And yet all these "we" communities coexisted within the same physical territory, and moved through the same heres even as they brought multitudinous elsewheres with them.

Though it is beyond the scope of this article to elaborate, it is worth noting that these overlapping diasporic, regional, and linguistic print worlds within colonial Malaya have rarely been brought into analytical dialogue with one another. Indeed, it is inordinately difficult to discern where they addressed each other at the time. When Luo Jiongxiong called out to his fellow "gentlemen of conscience," he was certainly not addressing, for example, Malay-, Arabic-, or Tamil-language newspaper readers with whom he lived cheek by jowl in the city of Kuala Lumpur or the rest of the territory of British Malaya. And when for example the Majalah Guru, a Malay-language newspaper published in Seremban (a city south of Kuala Lumpur) in 1924 announced in its inaugural issue that the paper represented "the best place from which to contact 'the many," that 
"many" undoubtedly did not include Luo Jiongxiong's gentlemen of conscience. ${ }^{90}$ As Tim Harper observed of the "diasporic public sphere" of Singapore, "historians have written about how specific diasporas came to terms with their new environment, but have said little about how different diasporas conversed with each other." 91 No more so than in a colonial space so full of them.

And yet, the synchronicity of these editorial endeavours was surely significant, as much recent scholarship on temporality has begun to suggest. The May Fourth movement has been a major point of reference for China, often appearing as the central linchpin of the dawn of Chinese modernity, a great rupture associated with a violent antitraditionalism and a self-conscious fetishisation of the new and the radical, ${ }^{92}$ and a "diasporic moment" of heightened transnational Chinese patriotism. Sebastian Conrad and Dominic Sachsenmaier, however, have argued for the arc of the 1880 s to the 1930s as a coherent time period characterised by globalisation, the essential continuation of colonial rule, convergent tropes of belonging, and the globalising of oppositional movements that sought to redefine and push back against an amassing, dominant world order. ${ }^{93}$ In this more global frame, the May Fourth movement appears not merely as a moment of Chinese nationalism, but as one of many synchronous mass movements of the era, and the broader period in which it sits, one of multiple overlapping reformist-oriented modernities.

How, then, do we locate the diasporic yet synchronous print publics of colonial Malaya at this global conjuncture of the early twentieth century and the cultural geographies they invoked and domesticated? ${ }^{94}$ How do we deal, analytically, with their coexistence? What should we make of the fact that, for example, Al-Imam, the Malay-language Arab-inflected Islamic reform journal, commenced publication in Singapore in the same year, 1907, as the vigorous Chinese-language reform journal Zonghui bao (Union Times), seemingly without a single point of intersection or interaction between them, each with synchronous sets of claims to the modern? ${ }^{95}$ How do we think about the transregionality, transnationality, and the parallel coexistence of thinking, reading, and protesting colonial publics in a moment like 1919? What did colonialism itself have to do with both their intellectual synchronicities and the boundaries of race, language, and power that kept them apart? Much in this vein remains to be done.

\section{Conclusion}

If publics exist by virtue of being addressed, what public is "called into being" by a paper such as the Yik Khuan Poh? I have tried to illustrate two arguments. First, the "Chinese public" addressed and convened by the $Y K P$ was no culturally unified thing whose dimensions can be forced, as Arif Dirlik has cautioned us, into a single coherent history of the "transnational Chinese press," nor one which can be said simply to address a transnational Chinese readership. In recovering the productive ambiguity of "we", rather than "Chinese", as an organizing principle for the publics convened in the YKP, I have stressed the translocal gradations and relationalities that exist within the "transnational 
we" which models of diaspora tend to assume, and overdetermine. I have also examined the regionality of the paper, with one condition for its emergence being the social networks an editor brought to a newspaper, and the ideological affinities he espoused, as well as the need for a constant negotiation of the tensions between "here" and "elsewhere". Among other things, these enable us to recognize that what Benedict Anderson called Isobelo de los Reyes' "pronominal slippages" and unbounded audiences were perhaps features rather than exceptions of the late nineteenth and early twentieth centuries. In the case of ascribed "diasporic" Chinese communities of this era, this unboundedness was a fateful tension that became resolvable only toward the ethnonational, at the expense, potentially, of alternative genealogies of belonging to the region and the world. ${ }^{96}$

Secondly, and equally, the colonial print space is not one which we can think of as coterminous with a national public sphere. In this paper I have suggested that the "colonial" quality of a public sphere must at least in part consist in its compound, syncopated, and polyphonic nature: one predicated on language, and not only, or necessarily, on race and ethnicity, ${ }^{97}$ as well as one which, even in a strong "diasporic moment," is layered and textured with many different geographies of collective belonging. It is a space in which first person plurals overlap and coexist within a shared territory that can be designated neither fully public nor fully private, and indeed, contains always within it the potential of crisis at the point of exposure of one "private" reading public to the other. And it is perhaps one which, taking the global frame of reference that is so frequently the mental scaffolding upon which the contents of early twentieth-century newspapers are erected, it might not suffice to refer to as merely "Chinese."

\section{Acknowledgements}

I am grateful to Emma Hunter and Leslie James for inviting me to contribute to this project, and to Howard Chiang, Henrietta Harrison, Sai Siew-min, Rudolf Wagner, and the two anonymous reviewers for their comments on earlier drafts. I also thank Chua Hui Chuan and Sarah Wilson for research assistance. Various parts of this paper were presented at Warwick University, Cambridge University, and National University of Singapore; I am grateful for feedback and insights gleaned from these interactions. All errors remain my own.

\section{Bibliography}

\section{Published Primary Sources}

Haiyuguke. Jiefang bie lu. Taipei: Wen hai chu ban she. 1968.

Liu Shixin. "Guanyu wuzhengfuzhuyi huodong de diandi huiyi." In Wuzhengfu zhuyi sixiang ziliao xuan, edited by Ge Maochun, Jiang Jun, and Li Xingzhi. Beijing: Beijing University Press, 1984.

—_. "Liu Shixin de huiyi." In "Yi da" qianhou: Zhongguo gongchandang di yi ci daibiao da hui qianhou ziliao xuanbian, edited by General National Congress of the Chinese Communist Party. Beijing: Renmin chuban she, 1985.

YKP (Yik Khuan Poh/Yiqun bao), 1919-1936. 


\section{Published Secondary Sources}

Anderson, B. Imagined Communities: Reflections on the Origin and Spread of Nationalism. New York: Verso Books, 2006.

Ballantyne, T., and A. Burton. Bodies in Contact: Rethinking Colonial Encounters in World History. 2nd ed. Durham, N.C.: Duke University Press, 2006.

Carstens, Sharon A. "Chinese Publications and the Transformation of Chinese Culture in Singapore and Malaysia." In Changing Identities of the Southeast Asian Chinese since World War II, edited by Jennifer Cushman and Gungwu Wang, 75-95. Hong Kong: Hong Kong University Press, 1988.

Cartier, Carolyn L. Globalizing South China. Oxford: Blackwell, 2001.

Chan, Shelly. "The Case for Diaspora: A Temporal Approach to the Chinese Experience." Journal of Asian Studies 74:1 (2015), 107-28.

—. Diaspora's Homeland: Modern China in the Age of Global Migration. Durham, N.C.: Duke University Press, 2018.

Cheek, Timothy. The Intellectual in Modern Chinese History. Cambridge: Cambridge University Press, 2016.

Chen, Joseph. The May Fourth Movement in Shanghai: The Making of a Social Movement in Modern China. Leiden: Brill, 1971.

Chen, Leslie. Chen Jiongming and the Federalist Movement: Regional Leadership and Nation Building in Early Republican China. Ann Arbor: University of Michigan, 1999.

Chen, Mong Hock. The Early Chinese Newspapers of Singapore, 1881-1912. Singapore: University of Malaya Press, 1967.

Cheung, Gary and Owen Fung. "Why Beijing's headache over calls for Hong Kong's independence has only just begun." South China Morning Post, 26 August 2016, <https://www.scmp.com/ week-asia/politics/article/2009538/why-beijings-headache-over-calls-hong-kongs-independencehas-only>, accessed 2 July 2020.

Chow, Tse-Tsung. The May Fourth Movement: Intellectual Revolution in Modern China. Cambridge, Mass.: Harvard University Press, 1960.

Conrad, Sebastian, and Dominic Sachsenmaier, eds. Competing Visions of World Order: Global Moments and Movements, 1880s-1930s. London: Palgrave Macmillan, 2007.

Cooper, Frederick. Colonialism in Question: Theory, Knowledge, History. Berkeley: University of California Press, 2005.

Cui, Guiqiang. "Haixia zhimin di huaren dui wu si yundong di fanxiang." Nanyang Xuebao 20 (1965-66): 13-18.

Dirlik, Arif. "Anarchism and the Question of Place: Thoughts from the Chinese Experience." In Anarchism and Syndicalism in the Colonial and Postcolonial World, 1870-1940: The Praxis of National Liberation, Internationalism, and Social Revolution, edited by Steven Hirsch and Lucien Van der Walt. Leiden: Brill, 2010.

- "Performing the World: Reality and Representation in the Making of World Histor(ies)." Journal of World History 16:4 (2005), 391-410.

- "Transnationalism, the Press, and the National Imaginary in Twentieth-Century China." China Review 4:1 (2004), 11-25.

—. Anarchism in the Chinese Revolution. Berkeley: University of California Press, 1991.

Emmanuel, Mark. "A Life Unrecognized: Muhammad Yusuf Ahmad and Majalah Guru." In Lost Times and Untold Tales from the Malay World, edited by Jan Van der Putten and Mary Kilcine Cody, 164-76. Singapore: NUS Press, 2009.

Fabian, Johannes. Language and Colonial Power: The Appropriation of Swahili in the Former Belgian Congo, 1880-1938. Berkeley: University of California Press, 1991.

Fong, Vanessa. "Filial Nationalism among Chinese Teenagers with Global Identities." American Ethnologist 31:4 (2004), 631-48. 
Goodman, Bryna. "Semi-Colonialism, Transnational Networks and News Flows in Early Republican Shanghai." China Review (2004), 55-88.

Greiner, Clemens, and Patrick Sakdapolrak. "Translocality: Concepts, Applications and Emerging Research Perspectives." Geography Compass 7:5 (2013), 373-84.

Gries, Peter Hays. "Tears of Rage: Chinese Nationalist Reactions to the Belgrade Embassy Bombing." China Journal 46 (2001), 25-43.

Guo Huifen. "Zhongguo xin wenhua yundong zai dongnanya de chuanbo." In Wusi zai dongnanya, edited by Wang Runhua and Pan Guoju. Singapore: Bafang wenhua chuangzuo shi, 2019.

Habermas, Jürgen. The Structural Transformation of the Public Sphere: An Inquiry into a Category of Bourgeois Society. Cambridge, Mass.: MIT Press, 1989 [1962].

Harper, T. N. "Globalism and the Pursuit of Authenticity: The Making of a Diasporic Public Sphere in Singapore." SOJOURN 12:2 (1997), 261-92.

— Cambridge University Press, 2014.

Huang, Jianli. "Umbilical Ties: The Framing of the Overseas Chinese as the Mother of the Revolution." Frontiers of History in China 6:2 (2011), 183-228.

Hunter, Emma. Political Thought and the Public Sphere in Tanzania. Cambridge: Cambridge University Press, 2015.

Kenley, David. "Advertising Community: Union Times and Singapore's Vernacular Public Sphere, 1906-1939." Journal of World History 25:4 (2015), 583-609.

- New Culture in a New World: The May Fourth Movement and the Chinese Diaspora in Singapore, 1919-1932. New York: Routledge, 2003.

Krebs, Edward S. Shifu, Soul of Chinese Anarchism. London: Rowman \& Littlefield, 1998.

Kwan, Daniel. Marxist Intellectuals and the Chinese Labor Movement: A Study of Deng Zhongxia (1894-1933). Seattle: University of Washington Press, 1997.

Lee, Leo Ou-fan. "Incomplete Modernity: Rethinking the May Fourth Intellectual Project." In The Appropriation of Cultural Capital: China's May Fourth Project, edited by Milena Doleželová-Velingerová, Oldřich Král, and Graham Martin Sanders, 31-65. Cambridge Mass.: Harvard University Asia Center, 2001.

Leow, Rachel. Taming Babel: Language in the Making of Malaysia. Cambridge: Cambridge University Press, 2016.

Li, Zhi. "Jingwai de xin wenxue yuandi - Wusi shiqi Nanyang diqu wenyi fukan 'Xin Guomin Zazhi' yanjiu." Zhongguo xiandai wenxue yanjiu congkan, vol. 4 (2004).

Ma, Laurence, and Carolyn Cartier, eds. The Chinese Diaspora: Space, Place, Mobility, and Identity. Lanham, Md.: Rowman \& Littlefield Publishers, 2003.

Macauley, Melissa. "Entangled States: The Translocal Repercussions of Rural Pacification in China, 1869-1873." American Historical Review 121:3 (2016), 755-79.

Mandal, Sumit K. "Cultural Geographies of the Malay World: Textual Trajectories in the Indian Ocean." Philological Encounters 1 (2016), 370-95.

Milner, Anthony. The Invention of Politics in Colonial Malaya: Contesting Nationalism and the Expansion of the Public Sphere. Cambridge: Cambridge University Press, 2002.

Ou Xi. "Nanyang wuzhengfu zhuyi yundong zhi gaikuang." In Wuzhengfuzhuyi zai Zhongguo, edited by Gao Jun, 492-7. Changsha: Hunan renmin chuban she, 1984.

Ramnath, Maia. Haj to Utopia: How the Ghadar Movement Charted Global Radicalism and Attempted to Overthrow the British Empire. Berkeley: University of California Press, 2011.

Ricci, Ronit. Islam Translated: Literature, Conversion, and the Arabic Cosmopolis of South and Southeast Asia. Chicago: University of Chicago Press, 2011.

Sai, Siew-Min. "The Nanyang Diasporic Imaginary: Chinese Schoolteachers in a Transborder Setting in the Dutch East Indies." In Chinese Indonesians Reassessed: History, Religion and Belonging. London: Routledge, 2013. 
Shen Fushui, 'Feilubin huaqiao ge laodong tuanti lianhehui de zhandou li cheng', Guangdong wenshi ziliao, vol. 54 (March, 1988), 100-33.

Schulz-Forberg, Hagen, ed. A Global Conceptual History of Asia, 1860-1940. London: Pickering \& Chatto Publishers, 2014.

Seah, Leander. "Conceptualizing the Chinese World: Jinan University, Nanyang Migrants, and Trans-Regionalism, 1900-1941." PhD diss., University of Pennsylvania, 2011.

Wagner, Rudolf. Joining the Global Public: Word, Image, and City in Early Chinese Newspapers, 1870-1910. Albany: State University of New York Press, 2007.

_ . "Don't Mind the Gap! The Foreign-Language Press in Late-Qing and Republican China." China Heritage Quarterly 30/31 (2012).

Wang, Gungwu. "The Limits of Nanyang Chinese Nationalism, 1912-1937." In Southeast Asian History and Historiography: Essays Presented to D. G. E. Hall, edited by C. D. Cowan and O. W. Wolters, 405-23. Ithaca, N.Y.: Cornell University Press, 1976.

Wang, Q. Edward. "The May Fourth Movement: Ninety Years After." Chinese Studies in History 43:4 (2010), 3-5.

Warner, Michael. "Publics and Counterpublics." Public Culture 14:1 (2002), 49-90.

Wasserstrom, Jeffrey. Student Protests in Twentieth-Century China: The View from Shanghai. Berkeley: Stanford University Press, 1997.

Xie Zhongling. "Wu Dunmin yu Jilongpo 'Yiqun Bao."' In Xin Mahua zu wenshi lun cong, 26986. Singapore: Xin she, 1999.

Xu Jianfen. Tiebi chunqiu: Malaiya "Yi Qun Bao" fengyun lu. Kuala Lumpur: Xin she, 2003.

$\mathrm{Xu}$ Xiaoqun. Cosmopolitanism, Nationalism, and Individualism in Modern China: The Chenbao Fukan and the New Culture Era, 1918-1928. New York: Lexington Books, 2014.

Yen, Ching-Hwang. "Overseas Chinese Nationalism in Singapore and Malaya 1877-1912." Modern Asian Studies 16:3 (1982), 397-425.

Yong Ching Fatt. The Origins of Malayan Communism. Singapore: South Seas Society, 1997.

Yü, Ying-Shih. "Neither Renaissance Nor Enlightenment: A Historian's Reflections on the May Fourth Movement." In The Appropriation of Cultural Capital: China's May Fourth Project, edited by Milena Doleželová-Velingerová, Oldřich Král, and Graham Martin Sanders, 299320. Cambridge, Mass.: Harvard University Asia Center, 2001.

Zarrow, Peter. Anarchism and Chinese Political Culture. New York: Columbia University Press, 1990.

Zhou, Yongming. Historicizing Online Politics: Telegraphy, the Internet, and Political Participation in China. Stanford, Calif.: Stanford University Press, 2005.

\section{Notes}

* Rachel Leow is University Senior Lecturer in Modern East Asian History at Cambridge University. Her first monograph, Taming Babel: Language in the Making of Malaysia, published with Cambridge University Press in 2016, won the 2018 Harry J. Benda Prize in Southeast Asian Studies, and other writings have appeared in Journal of Asian Studies, Modern Asian Studies, Journal of Social History, Journal of World History, and Journal of Chinese Overseas.

1 Luo Jiongxiong, "Bian ji Qingdao lei xiao qi," YKP, 2 June 2019.
2 Literature on the May Fourth movement is vast; for a classic overview, see Chow, The May Fourth Movement. For a recent survey of the literature, see Wang, "The May Fourth Movement."

3 Habermas, Structural Transformation of the Public Sphere; Anderson, Imagined Communities.

4 For examples of the flattened, transplanted, or "taught nationalism" approach to overseas Chinese nationalism, see, e.g., Yen, "Overseas Chinese Nationalism"; Wang, "The Limits of Nanyang Chinese 
Nationalism." See also Huang, "Umbilical Ties," and Chan, Diaspora's Homeland.

5 See Michael Warner's comments in Leslie James, Karin Barber, Lara Putnam, and Michael Warner, "A Conversation: Revisiting Publics and Counterpublics" in this special issue.

6 Harper, "Globalism and the Pursuit of Authenticity." On cultural geographies, see Mandal, "Cultural Geographies of the Malay World."

7 On "cohabitation," a term used by Karin Barber to describe colonial Nigeria's "cohabitation of English and Yoruba," see Barber, in James et al., "A Conversation," in this issue. On Swahili, Fabian, Language and Colonial Power.

8 Benedict Anderson, Imagined Communities (London: Verso, 2006 [1983]), 154. For his wry admission of the original edition's "assuredly polemical" intentions, p. 208. It is in Anderson's later works, notably Spectre of Comparisons and Under Three Flags, where he begins to grapple with the pronominal and plurilingual fractures of print audiences with which my essay is concerned.

9 Harper and Amrith, Sites of Asian Interaction.

10 Barber, in James et al., "A Conversation," in this issue.

11 Benedict Anderson, Under Three Flags: Anarchism and the anti-colonial imagination (London: Verso, 2005), 24-5.

12 On the serial logics of the colonial state, and on "bounded" and "unbounded" serialities, see Benedict Anderson, The Spectre of Comparisons: Nationalism, Southeast Asia and the World (London: Verso, 1998), 29-45. I am grateful to Sai Siew-min for urging me to push this point more clearly.

13 Carstens, "Chinese Publications," 77. For a typical account of Southeast Asian Chinese intellectual trends as "imitating" (xuexi) or "emulating" ( fangxiao) mainland Chinese literary trends, see Guo, "Zhongguo Xin Wenhua Yundong," e,g, 92, 116.

14 Wagner, Joining the Global Public. See also other papers in this special issue.
15 For this critique, see Dirlik, "Transnationalism."

16 Yik Khuan Poh is the Hokkien transliteration of the newspaper's titular Chinese characters, which would be spelt Yiqun ribao or Yiqun bao in modern pinyin. In the title, both ribao, "daily newspaper", and bao, "newspaper", were in use concurrently. Yik Khuan Poh reflects the way its largely Hokkien-speaking readers would have pronounced the title and will be used throughout.

17 For a general history of the $Y K P$ see $\mathrm{Xu}$, Tiebi chunqiu.

18 YKP, 4 March 1920.

19 YKP, 7 July 1919. Compare this to other papers at the time: Le Bao: 650; Zonghui Bao (Union News): 1,650; Xin Guomin Ribao: 1,500; Straits Times: 4,000; Malay Tribune: 1,200. Kenley, New Culture in a New World, 101.

20 Most of what has been written about Wu Dunmin has focused on this "six gentlemen incident"; see Yong, The Origins of Malayan Communism, chap. 1. This formulation was often used to refer to incidences of intellectual oppression, often violent, with the implication of martyrdom for those so named; for example, the "Guangxu six gentlemen" of 1898 , in which six reformists were executed by order of the Empress Dowager Cixi, and which the use of this appellation for $\mathrm{Wu}$ Dunmin and his colleagues was undoubtedly referencing.

21 The Tokyo school of Chinese anarchism wielded a strong influence on early generations of sojourning Chinese intellectuals. For a brief background on $\mathrm{Wu}$, see Xie, "Wu Dunmin."

22 YKP, 1-2 March 1920.

$23 \mathrm{Wu}$ Dunmin, "Jieji zhidu liudu shehui lun," YKP, 14 April 1919.

24 YKP, 17 April 1919; 2 May 1919.

25 "Te bie kuai dian," $Y K P, 12$ May 1919.

$26 \mathrm{Wu}$ Dunmin, "Wei zai beijing da xuesheng," YKP, 15 May 1919.

$27 \mathrm{Wu}$ Dunmin, "Beijing xuesheng zhi ji ang," YKP, 23 May 1919. 
28 Wu Dunmin, "Wei Qingdao wenti zai gao qiaobao," YKP 22 May 1919.

29 On the san $b a$ see especially Wasserstrom, Student Protests; Chen, May Fourth Movement. For accounts of May Fourth-era protests in Singapore, see Kenley, New Culture in a New World and Cui, "Haixia zhimin di huaren."

$30 \mathrm{Wu}$ Dunmin, "Dizhi wo huo guanjian," YKP, 13 June 1919; see also Wu Dunmin, "Yuwang dizhi wo huo yizhi shixing zhe," YKP, 16 June 1919.

$31 \mathrm{Wu}$ Dunmin, "Yuwang dizhi wo huo yizhi shixing zhe," YKP, 16 June 1919.

32 “Anti-Japanese Outbreak," Straits Times, 21 June 1919.

33 For similar nationalist moments, see Gries, "Tears of Rage"; Fong, "Filial Nationalism." More recently, Shelly Chan, "The Case for Diaspora." Zhou Yongming has emphasised the importance of the telegraph in binding and convening transnational Chinese publics at certain moments; see Zhou, Historicizing Online Politics, especially 45-56, 65-7.

34 On publics created by attention, see point 4 in Warner, "Publics and Counterpublics."

35 Dirlik, "Transnationalism," 19.

36 Greiner \& Sakdapolrak, 377. Other useful inroads into the literature on translocalism for me have been Cartier, Globalizing South China; Dirlik, "Performing the World"; Ma and Cartier, The Chinese Diaspora; Macauley, "Entangled States."

37 Qiangquan can be taken to mean "arbitrary, unreasonable, or repressive power or authority," and zhuyi as meaning "-ism."

38 These thoughts are elaborated in the essays by Wu Dunmin, "Minzu zijue," "Minzhi yu zijue," "Minzu ziwei," "Minzu zizhi," serialised throughout YKP, 16-24 July 1919, henceforth "Minzu letters."

39 As reported in YKP, 8 July 1919.

40 "Liu junzi bei bu hou xiaoxi," $Y K P$, 16 August 1919.

41 Tan Mingqian, "De mo ke la xi zhi si mian guan," Xin Chao, 5 May 1919, republished in YKP, 20 August 1919.
42 Tan Mingqian, "De mo ke la xi zhi si mian guan."

43 By one estimate, in Chinese newspapers in Singapore at the time up to a third of a given issue's content might be "cut" from mainland newspapers; see $\mathrm{Li}$, "Jingwai De Xin Wenxue Yuandi." On the development of cutting as a practice, see Chen, Early Chinese Newspapers, 34-5.

44 "Liu junzi bei bu hou xiaoxi," $Y K P$, 16 August 1919.

45 "Ben po jin tian huaqiao quanti shangdian ba shi," YKP, 1 August 1919.

46 "Liu junzi hui guo hou qingxing," $Y K P$, 7 January 1920.

47 Studies of Chinese migration at the transregional scale include Seah, "Conceptualizing the Chinese World"; Sai, "The Nanyang Diasporic Imaginary."

48 Shifu's principal biography, still unsurpassed, is Krebs, Shifu.

49 Liu, "Liu Shixin de huiyi," 125. On the Xin Shiji and the New Century ideology, see Zarrow, Anarchism and Chinese Political Culture.

50 See Liang Bingxian's memoir, published under the pen name "Haiyuguke": Haiyuguke, Jiefang Bie Lu.

51 See Liu, "Guanyu wuzhengfu zhuyi huodong."

52 Liu, "Guanyu wuzhengfu zhuyi huodong," 935.

53 See the melodramatic but enthusiastic welcome penned by his colleague Tie Han, "Song Kefei," YKP, 4 March 1920.

54 On the Pingmin ribao and its broader publication context, see Shen Fushui, 'Feilubin huaqiao ge laodong tuanti lianhehui de zhandou li cheng', Guangdong wenshi ziliao, vol. 54 (March, 1988), 100-1. The Pingmin ribao's founding editor, Fu Wumen, also drifted across the South Seas to set up a similar labouroriented paper in Rangoon in the early 1920s; see Ou Xi, 496.

55 This format was used in earlier progressive Chinese periodicals; e.g., in the Chenbao Fukan: Xu, Chenbao Fukan. 
56 On the political shift of the $Y K P$ from a more ideologically pluralist to a Guomindang-dominated newspaper, see $\mathrm{Xu}$ Jianfen, Tiebi chunqiu, especially chap. 5.

57 Estimates by Xu Jianfen, Tiebi chunqiu, 61-3.

58 Xu Jianfen, Tiebi chunqiu, 73-4.

59 On the intrinsic didacticism of the early twentieth-century public sphere in China, see Cheek, The Intellectual in Modern Chinese History, 35-44. On "modernity" and "progress" as devices for claims-making in colonial societies, see Cooper, Colonialism in Question, 234; Emma Hunter, Political Thought and the Public Sphere in Tanzania.

60 On Shixin's acquaintance with Chen Jiongming see Liu Shixin, "Liu Shixin de huiyi," 126-7. On Chen Jiongming see Chen, Chen Jiongming.

61 Chen Jiongming in the Minxing bao in 1919, quoted in Chen, Chen Jiongming, 85.

62 Shifu also might have believed that the overseas Chinese communities in Southeast Asia represented a clear example of Kropotkinesque associative communities on which anarchist mutual aid could easily develop, and may have been one reason for anarchist activity in Southeast Asia. See Krebs, Shifu, Soul of Chinese Anarchism, 144. On anarchist activity in Southeast Asia, see Ou Xi, "Nanyang Wuzhengfu zhuyi yundong zhi gaikuang."

63 Xu Jianfen, Tiebi chunqiu, 74.

64 YKP, 21 May 1920.

$65 Y K P, 17$ June 1920.

$66 Y K P, 27$ November 1920; YKP, 18 December 1920.

67 See Wu Huilan, "Qiu hun han," $Y K P$, 6 December 1920, and follow-up at "Qiu hun han zhi weisheng," YKP, 23 December 1920.

68 See for example "Sui Gan Lu," YKP, 16 December 1920.

69 Goodman, "Semi-Colonialism," 2.

$70 \mathrm{Wu}$ Dunmin, "Jieshao zongzhi zhengda zhi ribao," YKP, 30 May 1919. See also periodic syndicated headlines from some of these newspapers, e.g., YKP, 27 July 1920.
71 James et al., "A Conversation," in this issue.

72 The youji (travelogue) genre of writing has been well established; on this see Xu Xiaoqun, Chenbao Fukan, 125-7.

73 "You Fei man lu," serialised in $Y K P$ throughout September 1920.

74 Exchange, Kefei and Jianzhi, Tongxin column, YKP, 15 June 1920.

75 On place and anarchism, see Arif Dirlik, "Anarchism and the Question of Place."

76 Ballantyne and Burton, Bodies in Contact.

77 For a suggestive series of studies in this direction, see Schulz-Forberg, A Global Conceptual History of Asia. For a study of a network of global radicalism, see Ramnath, Haj to Utopia.

78 Arif Dirlik, Anarchism in the Chinese Revolution; Peter Zarrow, Anarchism and Chinese Political Culture; in the Singaporean context, Yong Ching Fatt, "Origins and development of the Malayan Communist Movement".

79 Wagner, "Don't Mind the Gap."

80 "Japanese Boycott," Straits Times, 23 June 1919.

81 Malay Mail, 2 August 1919.

82 "'General Strike' at Kuala Lumpur," Straits Times, 4 August 1919.

83 See, e.g., articles on League of Nations and Germany throughout 4-16 May 1919 in the Straits Times, and the especially detailed coverage on 12 May of the terms of the peace treaty, which also includes a lamentation that the text of the treaty had not arrived in a timely fashion in Singapore, causing a delay in the reporting of it.

84 "China and Kiauchau," 13 May 1919.

85 Singapore Free Press, 25 June 1919.

86 On this, Leow, Taming Babel, chap. 1.

87 Singapore Free Press, 23 June 1919.

88 Enclosure in Alston to Tyrell, 22 June 1922, FO 371/8040, quoted in Kwan, Marxist Intellectuals, 97.

89 On this quality, see Leow, Taming Babel.

90 Inaugural issue of Majallah Guru, November 1924. On the magazine see Emmanuel, "A Life Unrecognized."

91 Harper, "Diasporic Public Sphere," 262. 
92 Though this view is depreciated in more recent scholarship; see especially Lee, "Incomplete Modernity"; Yü, "Neither Renaissance Nor Enlightenment."

93 Conrad and Sachsenmaier, Competing Visions of World Order.

94 For an evocative appraisal of the Malay world see Ricci, Islam Translated.

95 On Al-Imam, see Milner, Invention of Politics. On the Zonghui bao, see e.g. Chen, Early Chinese Newspapers; David Kenley, "Advertising Community."

96 This is undoubtedly why Anderson's work has been especially appealing to politically unusual, hybrid societies like Hong Kong and Taiwan, where there is a strong disconnect between the "we" that many feel themselves to be and the labels with which they are pigeonholed, or bounded, by the wider world. See, for example, Gary Cheung and Owen Fung's interview of Hong Kong independence activist Edward Leung Tin-kei, in Cheung and Fung, "Beijing's headache."

97 This makes it somewhat different from older "plural economy" conceptions of colonial space, on which see, classically, J. S. Furnivall, Colonial Policy and Practice (Cambridge: Cambridge University Press, 1948). 